\title{
ANALISIS PENGARUH PERBANKAN SYARI'AH TERHADAP INDUSTRI KREATIF DI SUMATERA UTARA TAHUN 2006 - 2015
}

\author{
Erni Yusnita Siregar* ,Saparuddin Siregar** ,Andri Soemitra*** \\ 'Universitas Islam Negeri Sumatera Utara Medan \\ ${ }^{2}$ Universitas Islam Negeri Sumatera Utara Medan \\ ${ }_{3}^{3}$ Universitas Islam Negeri Sumatera Utara Medan
}

\begin{abstract}
Abstrak
Artikel ini berupaya untuk menjelaskan pengaruh Jumlah Tenaga Kerja, Jumlah Perusahaan, Jumlah Ekspor dan Jumlah Pembiayaan Syari'ah terhadap PDRB Industri Kreatif di Sumatera Utara. Metode yang dipergunakan adalah metode kuantitatif dengan menggunakan menggunakan analisis regresi linier berganda/OLS (Ordinary Least Squared). Data yang digunakan pada penelitian ini adalah time series dengan periode dari tahun 2006 - 2015. Penelitian ini menemukan bahwa secara serempak menunjukkan bahwa sekitar $76,2 \%$ variabel jumlah tenaga kerja, jumlah perusahaan, jumlah ekspor dan jumlah pembiayaan syari'ah mempengaruhi PDRB Industri kreatif di Sumatera Utara periode 2006 - 2015, sedangkan 23,8\% dijelaskan oleh faktor-faktor lain. Secara parsial jumlah tenaga kerja, jumlah perusahaan, jumlah ekspor dan jumlah pembiayaan syari'ah memberi pengaruh terhadap PDRB Industri kreatif di Sumatera Utara.
\end{abstract}

Kata kunci: Tenaga Kerja, Perusahaan, Ekspor, Pembiayaan Syari’ah, PDRB

\begin{abstract}
This article aims to determine how much is the influence the Total Labor, Total Company, Total Export and Total shari'ah Financing, to the GDP of Creative Industries in North Sumatra Indonesia. The research method used is quantitative approach using path analysis with multiple linear regression analysis/ OLS (Ordinary Least Squared). The data used in this research is time series data in the period from 2006 - 2015. The study found that about $76,2 \%$ variable Total Labor, Total Company, Total Export and Total shari'ah Financing simultaneously influence the GDP of Creative Industries in North Sumatra in the period 2006 2015, while $23.8 \%$ is explained by other factors. Partially the Total Labor, Total Company, Total Export and Total shari'ah Finance, also giving effect to real GDP of Creative Industries in North Sumatra.
\end{abstract}

Keywords: Total Labor, Total Company, Total Export, Total shari’ah Financing, GDP

\section{PENDAHULUAN}

Konsep ekonomi kreatif merupakan sebuah konsep ekonomi di era ekonomi baru yang mengintensifkan informasi dan kreativitas dengan mengandalkan ide dan stock 
of knowledge dari sumber daya manusia sebagai faktor produksi utama dalam kegiatan ekonominya. Model pengembangan ekonomi kreatif layaknya sebuah bangunan yang akan menguatkan ekonomi Indonesia dengan landasan, pilar dan atap sebagai elemen - elemen bangunan tersebut. Industri kreatif merupakan bagian tak terpisahkan dari ekonomi kreatif. Ekonomi kreatif dapat dikatakan sebagai suatu sistem transaksi penawaran dan permintaan yang bersumber pada kegiatan ekonomi yang digerakkan oleh sektor industri yang disebut Industri Kreatif (Dani Danuar, 2013). Industri kreatif merupakan industri yang berasal dari kreativitas individu, ketrampilan, dan bakat yang secara potensial menciptakan kekayaan, dan lapangan pekerjaan melalui eksploitasi dan pembangkitan kekayaan intelektual dan daya cipta individu (Gunaryo, 2008). Pondasi industri kreatif adalah sumber daya insani yang merupakan elemen terpenting dalam industri kreatif. Pembangunan industri kreatif yang kompetitif harus dilandasi oleh pembangunan SDM yang terampil, terlatih dan terberdayakan untuk menumbuhkembangkan pengetahuan dan kreativitas (Henny Puspitasari, 2013).

Ekonomi kreatif terdiri dari kelompok luas professional, terutama mereka yang berada di dalam industri kreatif, yang memberikan sumbangan terhadap garis depan inovasi. Inteligen kreatif antara lain: seniman, artis, pendidik, mahasiswa, insinyur, dan penulis. Mereka seringkali mempunyai kemampuan berpikir menyebar dan mendapatkan pola yang menghasilkan gagasan baru (Gunaryo, 2008).

Gambar 1.1

Pergeseran Orientasi Ekonomi Dunia

Ekonomi Pertanian $\longrightarrow$ Ekonomi Industtri $\longrightarrow$ Ekonomi Informasi $\longrightarrow$ Ekonomi
Industri

Ekonomi kreatif sebenarnya adalah wujud dari upaya mencari pembangunan yang berkelanjutan melalui kreatifitas, yang mana pembangunan berkelanjutan adalah suatu iklim perekonomian yang berdaya saing dan memiliki cadangan sumber daya yang terbaharukan. Dengan kata lain ekonomi kreatif adalah manifestasi dari semangat bertahan hidup yang sangat penting bagi negara-negara maju dan juga menawarkan peluang yang sama untuk negara-negara berkembang. Republik Indonesia sendiri menyadari bahwa ekonomi kreatif adalah harapan bagi ekonomi Indonesia untuk bangkit bersaing dan meraih keunggulan dalam ekonomi global (Gunaryo, 2008).

Adapun Subsektor industri kreatif yang merupakan industri berbasis kreativitas adalah periklanan, arsitektur, pasar seni, kerajinan, desain, Fashion, video, film, fotografi, permainan interaktif, musik, seni pertunjukan, penerbitan dan percetakan, layanan 
komputer dan piranti lunak, televisi dan radio, serta riset dan pengembangan (Siti Nurjanah, 2013).

Sebagai pusat pertumbuhan ekonomi Indonesia bagian barat, Sumatera Utara (Sumut) berpotensi besar untuk pengembangan industri kreatif. Pertumbuhan ekonomi daerah diukur dengan pertumbuhan Pendapatan Domestik Regional Bruto (PDRB) menurut harga konstan. PDRB merupakan nilai tambah bruto seluruh barang dan jasa yang tercipta atau dihasilkan di wilayah domestik suatu negara yang timbul akibat berbagai aktivitas ekonomi dalam suatu periode tertentu tanpa memperhatikan apakah faktor produksi yang dimiliki residen atau non-residen (BPSSUMUT, 2016). Untuk menghitung angka-angka PDRB ada tiga pendekatan yang dapat digunakan yaitu pendekatan produksi, pendekatan pendapatan, dan pendekatan pengeluaran (BPS, 2016).

Secara konsep, tiga pendekatan tersebut akan menghasilkan angka yang sama. Produksi ini dikelompokkan menjadi 17 kategori lapangan usaha. Setiap kategori dirinci lagi menjadi beberapa subkategori diantaranya kategori Industri Pengolahan yang terdiri dari 16 subkategori yaitu Subkategori Industri Pengolahan Batubara dan Pengilangan Minyak dan Gas Bumi; Subkategori Industri Makanan dan Minuman; Subkategori Industri Pengolahan Tembakau; Subkategori Industri Tekstil dan Pakaian Jadi; Subkategori Industri Kulit, Barang dari Kulit, dan Alas Kaki; Subkategori Industri Kayu, Barang dari Kayu dan Gabus, dan Barang Anyaman; Subkategori Industri Kertas dan Barang dari Kertas, Percetakan, dan Reproduksi Media Rekam.

Kemudian subkategori Industri Kimia, Farmasi, dan Obat Tradisional; Subkategori Industri Karet, Barang dari Karet, dan Plastik; Subkategori Industri Barang Galian Bukan Logam; Subkategori Industri Logam Dasar; Subkategori Industri Barang Logam, Komputer, Barang Elektronik, Optik, dan Peralatan Listrik; Subkategori Industri Mesin dan Perlengkapan; Subkategori Industri Alat Angkutan; Subkategori Industri Furnitur; dan Subkategori Industri Pengolahan Lainnya, Jasa Reparasi, dan Pemasangan Mesin dan Peralatan.

Industri pengolahan merupakan kategori yang termasuk subsektor industri kreatif sedangkan kategori lainnya merupakan kategori non-sektor industri kreatif. Pada tahun 2015, nilai output industri besar dan sedang untuk kategori ini mencapai Rp 217,81 triliun dengan nilai tambah atas dasar harga pasar sebesar Rp 76,15 triliun. Nilai tambah terbesar pada tahun 2015 terdapat pada golongan industri industri kimia, batu bara, karet, dan plastik sebesar Rp 40,51 triliun. Kemudian diikuti oleh industri makanan, minuman dan tembakau yaitu sebesar Rp 28,76 triliun dan industri logam dasar sebesar Rp 1,81 triliun. Nilai tambah terkecil pada tahun yang sama terdapat pada golon- 
gan industri pengolahan lainnya sebesar Rp 102,24 milyar (BPSSUMUT, 2016).

Tabel 1.1

Nilai Tambah Industri Besar dan Sedang

Menurut Golongan Industri Atas Dasar Harga Pasar (Milyar rupiah)

\begin{tabular}{|c|c|c|c|}
\hline Lapangan Usaha & 2013 & 2014 & 2015 \\
\hline Golongan Industri & $(1)$ & $(2)$ & $(3)$ \\
\hline $\begin{array}{c}\text { Industri Makanan, minuman dan } \\
\text { tembakau }\end{array}$ & $21.173,74$ & $29.300,25$ & $28.764,18$ \\
\hline Industri tekstil, pakaian jadi dan kulit & 229,73 & 271,62 & 270,66 \\
\hline Industri kayu, perabot rumah tangga & 971,22 & $1.195,54$ & $1.062,90$ \\
\hline $\begin{array}{c}\text { Industri kertas, percetakan dan pener- } \\
\text { bit }\end{array}$ & 945,78 & $1.441,48$ & $1.422,16$ \\
\hline $\begin{array}{c}\text { Industri kimia, batubara, karet, dan } \\
\text { plastic }\end{array}$ & $54.400,77$ & $39.552,38$ & $40.512,30$ \\
\hline Industri Logam dasar & $1.721,30$ & $1.800,96$ & $1.811,38$ \\
\hline Industri Pengolahan lainnya & 34,25 & 32,51 & 102,24 \\
\hline
\end{tabular}

Sumber : Data diolah dari BPSSUMUT, 2016

Menurut berita resmi statistik Sumatera Utara yang terbit pada tanggal 6 Juni 2016 bahwa industri makanan, minuman dan tembakau menyerap tenaga kerja terbanyak yang berjumlah 74.800 orang diikuti dengan industri kimia, batubara, karet dan plastik. Untuk industri kayu, perabot rumah tangga sebesar 15.621 orang dan yang terendah yaitu industri pengolahan sebesar 1.825 .

Tabel 1.2

Jumlah Tenaga Kerja Industri Besar dan Sedang

Menurut Golongan Industri (Orang)

\begin{tabular}{|c|c|c|c|}
\hline Lapangan Usaha & 2013 & 2014 & 2015 \\
\hline Golongan Industri & $(1)$ & $(2)$ & $(3)$ \\
\hline $\begin{array}{c}\text { Industri makanan, minuman dan tem- } \\
\text { bakau }\end{array}$ & 69.695 & 74.772 & 74.800 \\
\hline Industri tekstil, pakaian jadi dan kulit & 4.503 & 4.041 & 4.005 \\
\hline Industri kayu, perabot rumah tangga & 16.368 & 14.564 & 15.621 \\
\hline Industri kertas, percetakan dan penerbit & 5.020 & 5.060 & 5.116 \\
\hline Industri kimia, batubara, karet, dan plastic & 50.692 & 38.396 & 38.115 \\
\hline Industri logam dasar & 4.747 & 4.385 & 4.403 \\
\hline Industri pengolahan lainnya & 2.655 & 1.929 & 1.825 \\
\hline
\end{tabular}


Sumber : Data diolah dari BPS SUMUT, 2016

Di Indonesia, sektor industri dikelompokkan atas industri skala besar, sedang, kecil dan rumah tangga. Pengelompokan ini didasarkan atas banyaknya jumlah tenaga kerja yang bekerja pada industri tersebut. Pada tabel 1.2 dijelaskan bahwa jumlah perusahaan terbanyak berada pada industri makanan, minuman dan tembakau hal ini terjadi sepanjang tahun 2013-2015. Yang diikuti industri kimia, batubara, karet, dan plastik, dan yang terendah adalah industri logam dasar. Industri kecil dan menengah merupakan salah satu sendi perekonomian di Indonesia. Sektor ini memegang peranan penting dalam peningkatan pertumbuhan ekonomi nasional (Henny Puspitasari, 2013).

Tabel 1.3

Jumlah Perusahaan Industri Besar dan Sedang Menurut Golongan Industri

(Unit)

\begin{tabular}{|c|c|c|c|}
\hline Lapangan Usaha & 2013 & 2014 & 2015 \\
\hline Golongan Industri & $(1)$ & $(2)$ & $(3)$ \\
\hline Industri makanan, minuman dan tembakau & 458 & 466 & 463 \\
\hline Industri tekstil, pakaian jadi dan kulit & 43 & 43 & 45 \\
\hline Industri kayu, perabot rumah tangga & 127 & 118 & 120 \\
\hline Industri kertas, percetakan dan penerbit & 28 & 28 & 27 \\
\hline Industri kimia, batubara, karet, dan plastic & 193 & 214 & 198 \\
\hline Industri logam dasar & 13 & 16 & 16 \\
\hline Industri pengolahan lainnya & 30 & 33 & 34 \\
\hline
\end{tabular}

Sumber : Data diolah dari BPSSUMUT, 2016

Ekspor merupakan bagian penting dari perdagangan luar negeri. Perdagangan luar negeri, dinegara manapun menjadi kebutuhan negara yang mempunyai makna bagi perkembangan ekonomi negaranya. Di dalam ekonomi Islam ekspor dilakukan tanpa merugikan negara mitra yang melakukan perdagangan internasional. Karena prinsipnya adalah saling menguntungkan bagi negara yang terlibat dalam perdagangan barang maupun jasa-jasa (Hasan Aedy, 2011). Hal ini menjadi kesempatan utama bagi para pengusaha dalam memperluas perdagangan hasil barang-barang industri. Sehingga ekspor ini diharapkan dapat berkontribusi terhadap PDRB industri kreatif di Sumatera Utara secara signifikan. Pada tahun 2014 ekspor barang-barang industri mengalami penurunan (7.850.784) dibandingkan pada tahun 2013, dan kembali meningkat pada tahun 2015 sebesar 7.956.089. 
Tabel 1.4

Ekspor Sumatera Utara Menurut Sektor (Milyar Rupiah)

\begin{tabular}{|c|c|}
\hline Tahun & Industri \\
\hline 2013 & 7.947 .434 \\
\hline 2014 & 7.850 .784 \\
\hline 2015 & 7.956 .089 \\
\hline
\end{tabular}

Sumber : Data diolah dari BPSSUMUT, 2016

Selanjutnya yang diharapkan dapat memberikan kontribusi terhadap PDRB industri kreatif di Sumatera Utara adalah pembiayaan bank-bank syariah yang dapat membantu para pengusaha untuk menjalankan industri dan memperluas industrinya. Salah satu tujuan pengembangan perbankan syariah adalah untuk memenuhi pembiayaan bagi pengembangan usaha yang berdasarkan prinsip kemitraan yaitu hubungan antarinvestor yang harmonis (Muhammad Syafi'i Antonio, 2001). Tabel 1.5 menunjukkan perkembangan dari pembiayaan usaha mikro kecil dan menengah. Yang pada tahun 2013 sampai pada tahun 2015 mengalami peningkatan, ini berarti bahwa bantuan dari lembaga keuangan sangat dibutuhkan bagi para pelaku industri dalam menjalankan perusahaannya.

Tabel 1.5

Perkembangan Baki Debet Kredit Usaha Mikro Kecil dan Usaha Menengah Menurut Lokasi Proyek Provinsi (Milyar Rupiah)

\begin{tabular}{|c|c|}
\hline Tahun & Sumatera Utara \\
\hline 2013 & $37.473,6$ \\
\hline 2014 & $45.199,7$ \\
\hline 2015 & $49.459,3$ \\
\hline
\end{tabular}

Sumber : (Data diolah) dari Bank Indonesia, 2016

Data Kredit UMKM sudah mencakup Bank umum konvensional dan Bank Syari'ah

Sebagaimana pada penelitian terdahulu yang dilakukan oleh Herie Saksono tahun 2012 (Herie Saksono, 2012) bahwa keberadaan ekonomi kreatif menjadi talenta baru yang diprediksi dapat memicu daya saing daerah. Hingga saat ini pengangguran, kemiskinan dan pertumbuhan ekonomi masih menjadi persoalan klasik yang memerlukan solusi. Ekonomi kreatif merupakan alternatif solusi permasalahan ekonomi. Dalam perkembangannya akan memberikan kontribusi ekonomi yang signifikan, menciptakan iklim bisnis yang positif, membangun citra dan identitas bangsa. Selain itu sumber daya dapat selalu terbaharukan yang berbasis pengetahuan, kreativitas, menuju keunggulan kompetitif bangsa. 
Erni Yusnita Siregar, Saparuddin Siregar, Andri Soemitra: Industri Kreatif

Penelitian ini menjelaskan pengaruh jumlah tenaga kerja, jumlah perusahaan, jumlah ekspor dan jumlah pembiayaan syari'ah terhadap PDRB industri kreatif di Sumatera Utara. Sedangkan metode yang dipergunakan adalah metode analisis regresi linear berganda dengan variabel yaitu jumlah tenaga kerja, jumlah perusahaan, jumlah eskpor, jumlah pembiayaan syari'ah dan PDRB industri kreatif. Untuk menganalisis variabel - variabel tersebut peneliti menggunakan data time series dengan kurun waktu dari tahun 2006 - 2015. Data sekunder ini bersumber dari laman situs BPS SUMUT dan center data base Bank Indonesia dengan alamat situs bi.go.id serta laman situs terkait dengan penelitian dan dapat dipercaya keakuratan dan sumber datanya.

\section{KAJIAN LITERATUR}

\section{A. Industri Kreatif}

Defenisi industri kreatif yang saat ini banyak digunakan oleh banyak pihak yang berkecimpung dalam industri kreatif adalah defenisi berdasarkan UK DCMS (Department of Culture, Media, and Sport) Task Force di Inggris tahun 1998: "Creative Industries as those industries which have their origin in individual creativity, skill and talent, and which have a potential for wealth and job creation through the generation and exploitation of intellectual property and content". ("Industri kreatif merupakan industri yang berasal dari kreativitas individu, ketrampilan, dan bakat yang secara potensial menciptakan kekayaan, dan lapangan pekerjaan melalui eksploitasi dan pembangkitan kekayaan intelektual dan daya cipta individu") (Gunaryo, 2008).

Studi pemetaan industri kreatif yang telah dilakukan oleh Departemen Perdagangan Republik Indonesia tahun 2007 juga menggunakan acuan defenisi industri kreatif yang sama, sehingga industri kreatif di Indonesia dapat didefenisikan sebagai berikut:"Industri yang berasal dari pemanfaatan kreatifitas, keterampilan serta bakat individu untuk menciptakan kesejahteraan serta lapangan pekerjaan melalui penciptaan dan pemanfaatan daya kreasi dan daya cipta individu tersebut (Gunaryo, 2008).

Dari definisi diatas dapat ditarik kesimpulan bahwa industri kreatif merupakan industri yang memanfaatkan kreativitas dan inovasi yang bertujuan untuk menyalurkan keterampilan dan bakat sehingga bisa tercipta lapangan pekerjaan melalui kreatifitas dan inovasi.

\section{B. PDRB}

PDRB merupakan nilai tambah bruto seluruh barang dan jasa yang tercipta atau dihasilkan di wilayah domestik suatu negara yang timbul akibat berbagai aktivitas ekonomi dalam suatu periode tertentu tanpa memperhatikan apakah faktor produksi yang dimiliki residen atau non-residen (BPS, 2016). Perencanaan pembangunan 
ekonomi, memerlukan berbagai macam data statistik sebagai dasar berpijak dalam menentukan strategi kebijakan, agar sasaran pembangunan dapat dicapai dengan tepat. Strategi kebijakan yang telah diambil pada masa-masa lalu perlu dimonitor dan dievaluasi hasil-hasilnya. Berbagai data statistik yang bersifat kuantitatif diperlukan untuk memberikan gambaran tentang keadaan pada masa yang lalu dan masa kini serta sasaran-sasaran yang akan dicapai pada masa yang akan datang.

Pada hakekatnya, pembangunan ekonomi adalah serangkaian usaha dan kebijakan yang bertujuan untuk meningkatkan taraf hidup masyarakat, memperluas lapangan kerja, memeratakan distribusi pendapatan masyarakat, meningkatkan hubungan ekonomi regional dan melalui pergeseran kegiatan ekonomi dari sektor primer ke sektor sekunder dan tersier (BPS, 2016). Dengan kata lain arah dari pembangunan ekonomi adalah mengusahakan agar pendapatan masyarakat naik, disertai dengan tingkat pemerataan yang sebaik mungkin. Untuk mengetahui tingkat dan pertumbuhan pendapatan masyarakat, perlu disajikan statistik pendapatan nasional/regional secara berkala. Data/indikator statistik tersebut dapat digunakan sebagai bahan masukan bagi penyusunan perencanaan pembangunan nasional atau regional khususnya di bidang ekonomi.

\section{Determinan PDRB}

1. Tenaga Kerja

Tenaga kerja adalah setiap orang yang mampu melakukan pekerjaan guna menghasilkan barang dan jasa baik untuk memenuhi kebutuhan sendiri maupun untuk masyarakat (BPSSUMUT, 2016). Bekerja merupakan sesuatu yang dibutuhkan oleh manusia. Kebutuhan itu bisa bermacam-bermacam, berkembang dan berubah, bahkan sering kali tidak disadari oleh pelakunya. Seseorang bekerja karena ada sesuatu yang hendak dicapainya, dan orang berharap bahwa aktivitas kerja yang dilakukannya akan membawanya kepada suatu keadaan yang lebih memuaskan dari pada keadaan sebelumnya. Dengan demikian dapat dikatakan bahwa pada diri manusia terdapat kebutuhan-kebutuhan yang pada saatnya membentuk tujuan-tujuan yang hendak dicapai dan dipenuhinya. Demi mencapai tujuan-tujuan itu, orang terdorong melakukan suatu aktivitas yang disebut kerja (Henny Puspitasari, 2013).

Dalam ekonomi Islam tenaga kerja adalah segala kegiatan manusia baik jasmani maupun rohani yang dicurahkan dalam proses produksi untuk menghasilkan barang dan jasa maupun faedah suatu barang (BPS, 2016). Tenaga kerja merupakan faktor produksi yang diakui oleh setiap sistem ekonomi baik ekonomi Islam, kapitalis, dan sosialis. Walaupun demikian sifat faktor produksi dalam Islam berbeda. 
Perburuhan sangat tergantung pada kerangka moral dan etika. Faktor pembeda etika kerja berdasarkan syari'ah dengan etika lainnya adalah berkaitan dengan niat, cara memilih tujuannya, serta sumber penentuan nilai. Etika kerja Islam mengandung dua dimensi yaitu ukhrawi dan duniawi (Hasan Aedy, 2011).

Tenaga kerja manusia dapat diklasifikasikan menurut tingkatannya (kualitasnya) yang terbagi atas (Muhammad Syafi'i Antonio, 2001):

1. Tenaga kerja terdidik (skilled labour) adalah tenaga kerja yang memperoleh pendidikan baik formal maupun non formal, seperti guru, dokter, pengacara, akuntan psikologi, dll.

2. Tenaga kerja terlatih (trained labour) adalah tenaga kerja yang memperoleh keahlian berdasarkan latihan dan pengalaman. Misalnya montir, tukang kayu, tukang ukir, sopir, teknisi, dll.

3. Tenaga kerja tak terdidik dan tak terlatih (unskilled and untrained labour) adalah tenaga kerja yang mengandalkan kekuatan jasmani daripada ruhani, seperti tenaga kuli pikul, tukang sapu, pemulung, buruh tani, dll.

\section{Ekspor}

Ekspor adalah proses transportasi barang atau komoditas dan jasa dari suatu negara ke negara lain secara legal, umumnya dalam proses perdagangan. Proses ekspor adalah tindakan untuk mengeluarkan barang atau komoditas dan jasa dari dalam negeri untuk memasukkannya ke negara lain (Rahman Hakim, 2012). Ekspor barang secara besar membutuhkan campur tangan dari bea cukai di negara pengirim maupun penerima. Ekspor merupakan bagian penting dari perdagangan internasional. Ekspor dapat diartikan sebagai total penjualan barang yang dapat dihasilkan oleh suatu negara, kemudian diperdagangkan kepada negara lain dengan tujuan mendapatkan devisa. Suatu negara dapat mengekspor barang-barang yang dihasilkan ke negara lain yang tidak dapat menghasilkan barang-barang yang dihasilkan negara pengekspor.

Ada beberapa faktor yang dapat menentukan daya saing suatu komoditi ekspor yaitu (Andrian Sutedi, 2014):

1. Faktor langsung terdiri atas:

a) Mutu komoditi, mutu komoditi pada dasarnya ditentukan oleh komposisi antara seni (art), nilai teknis, dan selera pemakainya. Mutu komoditi ditentukan oleh desain atau bentuk dari komoditi bersangkutan atau spesifikasi teknis dari komoditi tertentu, fungsi atau kegunaan dari komoditi 
tersebut bagi konsumen dan durability atau daya tahan dalam pemakaian.

b) Biaya produksi dan penentu harga jual. Harga jual pada umumnya ditentukan oleh salah satu dari biaya produksi ditambah mark up (magin keuntungan), disesuaikan dengan tingkat harga pasar yang sedang berlaku (Current market price), dan harga dumping.

2. Faktor tidak langsung terdiri atas:

a) Kondisi sarana pendukung ekspor seperti: fasilitas perbankan, fasilitas transportasi, fasilitas birokrasi pemerintahan, fasilitas surveyor, fasilitas bea cukai, dll

b) Insentif atau subsidi pemerintah untuk ekspor

c) Kendala tarif dan non tarif

d) Tingkat efisiensi dan disiplin nasional

e) Kondisi ekonomi global seperti: resesi dunia, proteksionisme, restrukturisasi perusahaan dan re-group global (kerjasama global).

\section{Jumlah Perusahaan}

Perusahaan atau usaha industri adalah suatu unit (kesatuan) usaha yang melakukan kegiatan ekonomi, bertujuan menghasilkan barang atau jasa, terletak pada suatu bangunan atau lokasi tertentu, dan mempunyai catatan administrasi tersendiri mengenai produksi dan struktur biaya serta ada seorang atau lebih yang bertanggung jawab atas usaha tersebut (M.L Jhighan, 2014). Sementara itu, dalam arti sederhana orang yang memiliki perusahaan dinamakan pengusaha. Pengusaha berarti seorang pemimpin ekonomi yang mempunyai kemampuan untuk mendapatkan peluang secara berhasil memperkenalkan mata dagangan baru, teknik baru, sumber pemasukan baru, dan merangkum pabrik, peralatan, manajemen, dan tenaga buruh yang diperlukan serta mengorganisasikannya ke dalam suatu teknik pengoperasian perusahaan. Apapun bentuk tatanan ekonomi dan politik negara itu, kewiraswastaan merupakan faktor penting bagi pembangunan ekonomi. Di negara sosialis, negara bertindak sebagai pengusaha. Begitu juga halnya di negara terbelakang dimana pengusaha swasta kurang berani mengambil resiko usaha baru. Sedang pada masyarakat kapitalis maju, pengusaha swasta memainkan peranan penting dalam pembangunan ekonomi negara tersebut.

Pada umumnya setiap perusahaan akan berusaha untuk bisa mendapatkan keuntungan sebesar-besarnya dalam bisnisnya. Untuk mencapai hal tersebut, perusahaan harus bisa masuk ke pasar yang kadangkala banyak hambatan atau barrier 
untuk bisa menawarkan barangnya kepada konsumen. Setelah masuk pasar, perusahaan berhadapan dengan persaingan di pasar. Untuk bisa masuk ke pasar, biasanya di pasar sudah ada produsen lain yang juga menawarkan barangnya kepada kelompok konsumen yang sama. Dengan demikian, untuk masuk pasar, produsen biasanya berperilaku berani tampil beda (product differentiation) dengan produsen yang sudah ada di pasar. Usaha untuk mendiferensiasikan produk membutuhkan biaya, sedangkan harga-harga yang lebih tinggi menurunkan kuantitas yang diminta oleh karena itu perusahaan harus menempatkan dalam pasar dengan memilih harga, kuantitas dan derajat diferensiasi produk yang dapat memaksimumkan keuntungan mereka. Bentuk keistimewaan diferensiasi produk antara lain karakteristik produk, citra produk dan karakteristik penjual (Tati Suhartati Joesran dan M. Fathorrazi, 2012).

Agar perusahaan dapat unggul atas pesaingnya, perusahaan harus menerapkan strategi diferensiasi, yang terdiri atas beberapa langkah, yaitu (Ria Satriyarini, 2016):

1. Evaluate competitive messages, dimana perusahaan berusaha untuk menganalisis material pemasaran apa yang selama ini dilakukan, apa kekurangannya serta apa keunggulan yang dimiliki perusahaan dibandingkan dengan pesaingnya.

2. Finds what makes you unique, yaitu dimana perusahaan dapat menunjukkan apa yang membuat karakteristik produknya berbeda dari pesaing.

3. Tell the world, berusaha untuk memberitahu konsumen bahwa produk kita memiliki keunggulan tertentu.

4. Keep your promise, tujuan dari diferensiasi adalah agar konsumen loyal. Maka agar konsumen tidak berpindah keproduk pesaing, maka yang harus dilakukan oleh perusahaan adalah berusaha terus untuk memuaskan konsumennya.

\section{Pembiayaan Bank Syari’ah}

Pengertian pembiayaan dalam ekonomi islam diartikan sebagai penyediaan dana atau tagihan yang dipersamakan dengan itu berupa: transaksi bagi hasil dalam bentuk mudharabah dan musyarakah, transaksi sewa menyewa dalam bentuk ijarah atau sewa beli dalam bentuk ijarah muntahiyah bittamblik, transaksi jual beli dalam bentuk piutang murabahah, salam dan istish'na, transaksi pinjam meminjam dalam bentuk piutang qardh dan transaksi sewa menyewa jasa dalam bentuk ijarah untuk transaksi multijasa berdasarkan persetujuan atau kesepakatan an- 
tara bank syariah serta UUS dan pihak lain yang mewajibkan pihak yang dibiayai atau diberi fasilitas dana untuk mengembalikan dana tersebut setelah jangka waktu tertentu dengan imbalan ujrah, tanpa imbalan atau bagi hasil (Binti Nur Asiyah, 2015).

Pemberian kredit atau permodalan kepada pelaku UMKM secara langsung akan mempengaruhi volume usaha bilamana hal tersebut digunakan menjadi modal kerja. Jika kredit tersebut digunakan untuk investasi atau untuk melakukan diversifikasi usaha, maka akan meningkatkan kesempatan kerja, yang pada akhirnya akan menambah volume usaha juga. Pertambahan volume usaha tersebut akan dapat meningkatkan pendapatan bagi UKM maupun tenaga kerja yang bekerja pada perusahaan tersebut (Zamroni, 2013).

Adapun fungsi dari pembiayaan yang diselenggarakan oleh bank syariah adalah (Binti Nur Asiyah, 2015):

1. Meningkatkan daya guna uang yaitu para penabung menyimpan uangnya di bank dalam bentuk giro, tabungan dan deposito. Uang tersebut dalam persentase tertentu ditingkatkan kegunaannya oleh bank guna suatu usaha peningkatan produktivitas.

2. Meningkatkan daya guna barang. Produsen dengan bantuan pembiayaan bank dapat mengubah bahan mentah menjadi bahan jadi sehingga utility bahan tersebut meningkat.

3. Meningkatkan peredaran uang. Pembiayaan yang disalurkan melalui rekening-rekening koran pengusaha menciptakan pertambahan peredaran uang giral dan sejenisnya seperti cek, bilyet, giro, wesel, promes dsb.

4. Menimbulkan semangat berusaha. Pembiayaan yang diterima pengusaha dari bank kemudian digunakan memperbesar volume usaha dan produktivitasnya.

5. Stabilitas ekonomi. Dalam ekonomi yang kurang sehat, langkah-langkah stabilisasi diarahkan pada usaha-usaha: pengendalian inflasi, peningkatan ekspor, rehabilitasi prasarana dan pemenuhan kebutuhan pokok rakyat untuk menekan arus inflasi dan untuk usaha pembangunan ekonomi maka pembiayaan memegang peranan penting. 


\section{KAJIAN TERDAHULU}

Adapun beberapa hasil kajian atau penelitian terdahulu yang relevan dengan penelitian ini adalah:

Luh Diah Citraresmi Cahyadi (2013) menyatakan bahwa modal, investasi, dan teknologi berpengaruh signifikan terhadap jumlah produksi pada industri pakaian jadi di Kota Denpasar. Sedangkan tingkat upah tidak berpengaruh signifikan terhadap jumlah produksi pada industri pakaian jadi. Dapat disimpulkan bahwa, variabel modal, investasi, dan teknologi hanya mempengaruhi jumlah produksi tetapi secara tidak langsung tidak mempengaruhi penyerapan tenaga kerja pada industri pakaian jadi di Kota Denpasar.

Enik Kusminarti (2015) menyatakan bahwa tingkat investasi yang berupa PMDN berpengaruh positif dan signifikan terhadap industri pengolahan di Jawa Timur. Sedangkan untuk PMA, juga berpengaruh positif namun tidak signifikan terhadap industri pengolahan di Jawa Timur. Kemudian jumlah tenaga kerja mempunyai pengaruh positif dan signifikan terhadap industri pengolahan di Jawa Timur. Sehingga jika ada peningkatkan jumlah tenaga kerja yang bekerja di industri pengolahan maka akan meningkatkan output. Peningkatan output berarti pula peningkatan PDRB industri pengolahan.

Aris Munandar (2016) menyatakan bahwa faktor - faktor yang mempengaruhi Pertumbuhan Ekonomi Provinsi di Indonesia adalah Pengeluaran Pemerintah, PMA, PMDN dan Net Ekspor. Hasil Analisis mengenai pengaruh Pengeluaran Pemerintah, PMA, PMDN dan Net Ekspor terhadap Pertumbuhan Ekonomi Provinsi di Indonesia menunjukkan hubungan yang positif signifikan.

\section{METODE PENELITIAN}

Penelitian ini menggunakan data sekunder berupa time series data, analisa statistik yang digunakan adalah dengan menggunakan regresi linier berganda. Maka model persamaannya adalah sebagai berikut :

$$
\mathrm{PDRB}=\alpha_{0}+\beta_{1} \mathrm{TNK}+\beta_{2} \mathrm{PRSH}+\beta_{3} \mathrm{EX}+\beta_{4} \mathrm{PSYRH}+e
$$

Keterangan :

$\begin{array}{ll}\text { PDRB }= & \text { Pertumbuhan Ekonomi Industri Kreatif berdasarkan harga } \\ & \text { konstan (Rp.Miliar) } \\ = & \text { intercept } \\ \alpha_{0} & =\text { Konstanta }\end{array}$


$\beta_{1}, \beta_{2}, \beta_{3}, \beta_{4}=$ Koefisien Regresi

$e \quad=$ Variabel pengganggu (disturbance error)

TNK = Jumlah Tenaga Kerja dari Industri Kreatif (Orang)

$\mathrm{PRSH}=$ Ekspor dari Industri Kreatif(Unit)

EX $\quad=$ Jumlah Perusahaan dari Industri Kreatif (Rp.Miliar)

PSYRH = Pembiayaan Syari'ah dari Industri Kreatif (Rp.Miliar)

Temuan dan Pembahasan Hasil Penelitian

\section{Statistik Deskriptif}

Analisis deskriptif memberikan gambaran atau deskripsi suatu data yang dilihat dari nilai mean (rata-rata), standar deviasi, nilai maksimum data, nilai minimum data, dsb. Adapun statistik deskriptif dari data penelitian ini dapat dilihat pada tabel dibawah ini.

Tabel 4.3

Hasil Statistik Deskriptif

\begin{tabular}{|l|l|l|l|l|l|}
\hline & $\begin{array}{l}\text { PDRB Industri } \\
\text { Kreatif }\end{array}$ & $\begin{array}{l}\text { Jumlah } \\
\text { Tenaga } \\
\text { Kerja }\end{array}$ & $\begin{array}{l}\text { Jumlah } \\
\text { Perusa- } \\
\text { haan }\end{array}$ & $\begin{array}{l}\text { Jumlah Ek- } \\
\text { spor }\end{array}$ & $\begin{array}{l}\text { Jumlah } \\
\text { Pem- } \\
\text { biayaan } \\
\text { Syari'ah }\end{array}$ \\
\hline Mean & 5935.35475 & 23346.7 & 176.8 & 1823586 & 8327.993 \\
\hline Median & 5490.416758 & 23278.68 & 168.6875 & 1793750 & 8294.833 \\
\hline Maximum & 8369.450391 & 25109.13 & 215.7031 & 2009939 & 12574.59 \\
\hline Minimum & 3658.564531 & 21245.41 & 159.2891 & 1642881 & 4418.798 \\
\hline $\begin{array}{l}\text { Standar De- } \\
\text { viasi }\end{array}$ & 221.9282314 & 1216.223 & 16.80523 & 122305 & 2415.79 \\
\hline $\begin{array}{l}\text { Sample Vari- } \\
\text { ance }\end{array}$ & 1970085.596 & 1479198 & 282.4158 & 14958516767 & 5836039 \\
\hline Kurtosis & -1.259375639 & -1.07722 & -0.51943 & -1.538151134 & -1.021 \\
\hline Skewness & 0.366648588 & -0.20909 & 0.923569 & 0.204891164 & 0.156459 \\
\hline Sum & 237414.19 & 933868 & 7072 & 72943433 & 333119.7 \\
\hline Observasi & 40 & 40 & 40 & 40 & 40 \\
\hline
\end{tabular}

Sumber: Eviews 7 (Data Diolah), 2016 


\section{UJI ASUMSI KLASIK}

Uji normalitas dilakukan dengan uji Jarque Bera.

Gambar 4.1

Histogram - Normality Test

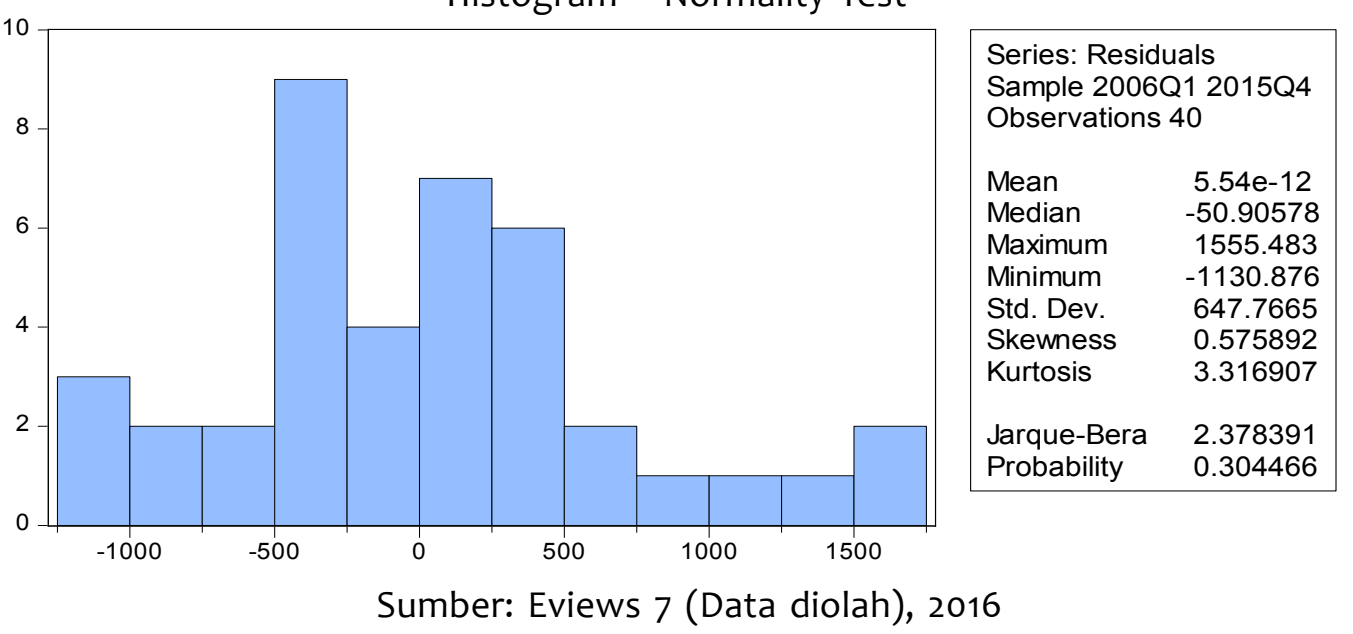

Dari grafik histogram di atas dengan melihat nilai probabilitas yang nilainya lebih besar dari tingkat signifikansi $\alpha=5 \%$ atau 0,304466 > 0,05 maka dapat disimpulkan bahwa distribusi data pada variabel penelitian adalah normal dan Ha diterima atau Ho ditolak.

Berdasarkan uji multikolinearitas menggunakan eviews7 maka diperoleh output regression sebagai berikut:

Tabel 4.4

Hasil Uji Multikolinearitas

\begin{tabular}{|l|l|l|l|l|}
\hline & TNK & PRSH & EX & PSYRH \\
\hline TNK & 1.000000 & 0.218908 & 0.552013 & 0.394363 \\
\hline PRSH & 0.218908 & 1.000000 & -0.488987 & -0.385958 \\
\hline EX & 0.552013 & -0.488987 & 1.000000 & 0.776701 \\
\hline PSYRH & 0.394363 & -0.385958 & 0.776701 & 1.000000 \\
\hline
\end{tabular}

Sumber: Eviews 7(Data diolah), 2016

Pada tabel hasil uji multikolinearitas di atas dapat dilihat bahwa nilai korelasi dari variabel bebas lebih kecil dari 0,8. Dengan demikian dapat disimpulkan bahwa tidak terdapat masalah multikolinearitas pada data penelitian ini.

Berdasarkan uji autokorelasi Breusch-Godfrey dengan menggunakan diferensi tingkat satu yaitu dengan memasukkan D(pdrb), D(tnk), D(prsh), D(ex), D(psyrh), c. sehingga diperoleh hasil estimasi sebagai berikut: 
Tabel 4.6

Hasil Uji Breusch-Godfrey Menggunakan Estimasi Diferensi Tingkat Satu

\begin{tabular}{|c|c|c|c|}
\hline \multicolumn{3}{|c|}{ Breusch-Godfrey Serial Correlation LM Test: } & \\
\hline F-statistic & 19.59211 & Prob. F(4,30) & 0.0000 \\
\hline Obs*R-squared & 0.000000 & Prob. Chi-Square(4) & 1.0000 \\
\hline
\end{tabular}

Sumber: Eviews 7(Data diolah), 2016

Berdasarkan output diatas maka tampak hasil nilai probabilitas Chi-Square adalah 1.000 nilai ini menunjukkan bahwa probabilitas Chi-Square $1.000>0,05$ yang mengindikasikan bahwa data tidak mengandung masalah autokorelasi.

Pengujian heterokedastisitas pada data penelitian dapat dilakukan dengan uji White Heterokedasticity yang dilakukan pada program eviews7. Setelah melakukan estimasi maka diperoleh hasil sebagai berikut:

Tabel 4.7

Hasil Uji White Heterokedasticity

\begin{tabular}{|c|c|c|c|}
\hline \multicolumn{3}{|c|}{ Heteroskedasticity Test: White } & \\
\hline F-statistic & 4.824776 & Prob. $\mathrm{F}(4,35)$ & 0.0033 \\
\hline Obs*R-squared & 14.21689 & Prob. Chi-Square(4) & 0.0066 \\
\hline Scaled explained SS & 12.60954 & Prob. Chi-Square(4) & 0.0133 \\
\hline
\end{tabular}

Sumber: Eviews7 (Data diolah), 2016

Dari tabel diatas menunjukkan bahwa nilai probabilitas Chi-Squared 0,0066 0,05. Hal ini menandakan bahwa terdapat masalah heterokedastisitas pada data penelitian. Untuk mengatasinya diambil suatu keputusan bahwa beberapa observasi harus dikurangi menjadi 24 observasi. Kemudian dilakukan estimasi kembali dengan program eviews7 maka dapat dilihat hasilnya sebagai berikut:

Tabel 4.8

Hasil Uji White Heterokedasticity

\begin{tabular}{|c|c|c|c|}
\hline \multicolumn{3}{|c|}{ Heteroskedasticity Test: White } & \\
\hline F-statistic & 2.009379 & Prob. F(4,19) & 0.1340 \\
\hline Obs*R-squared & 7.134546 & Prob. Chi-Square(4) & 0.1289 \\
\hline Scaled explained SS & 0.801835 & Prob. Chi-Square(4) & 0.9382 \\
\hline
\end{tabular}

Sumber: Eviews7 (Data diolah), 2016 
Erni Yusnita Siregar, Saparuddin Siregar, Andri Soemitra: Industri Kreatif

Dari tabel diatas dapat dilihat bahwa nilai probabilitas Chi-Squared 0,1289 > 0,05. Hal ini memberikan putusan bahwa tidak terdapat masalah heterokedastisitas dalam model regresi.

\section{ANALISIS REGRESI LINIER BERGANDA}

Tujuan dari analisis regresi berganda ini adalah untuk mengetahui dan memprediksi besar PDRB Industri Kreatif dengan menggunakan data TNK, PRSH, EX, dan PSYRH. Berdasarkan hasil pengolahan data secara ekonometrika dengan menggunakan program eviews maka didapat persamaan regresi sebagai berikut:

Tabel 4.9

Hasil Regresi Linier Berganda

\begin{tabular}{|c|c|c|c|c|}
\hline \multicolumn{3}{|c|}{ Dependent Variable: PDRB } & & \\
\hline \multicolumn{5}{|c|}{ Method: Least Squares } \\
\hline \multicolumn{5}{|c|}{ Date: 09/29/16 Time: 18:29 } \\
\hline \multicolumn{5}{|c|}{ Sample: 140} \\
\hline \multicolumn{5}{|c|}{ Included observations: 40} \\
\hline TNK & 0.612827 & 0.146255 & 4.190115 & 0.0002 \\
\hline PRSH & 69.80900 & 10.09704 & 6.913809 & 0.0000 \\
\hline EX & 0.004197 & 0.002018 & 2.080018 & 0.0449 \\
\hline PSYRH & 0.242133 & 0.072183 & 3.354426 & 0.0019 \\
\hline $\mathrm{C}$ & 9607.126 & 3105.161 & 3.093922 & 0.0039 \\
\hline R-squared & 0.787014 & \multicolumn{2}{|c|}{ Mean dependent var } & 5935.355 \\
\hline $\begin{array}{c}\text { Adjusted } \\
\text { R-squared }\end{array}$ & 0.762672 & \multicolumn{2}{|c|}{ S.D. dependent var } & 1403.597 \\
\hline S.E. of regression & 683.7806 & \multicolumn{2}{|c|}{ Akaike info criterion } & 16.00962 \\
\hline Sum squared resid & 16364455 & \multicolumn{2}{|c|}{ Schwarz criterion } & 16.22073 \\
\hline Log likelihood & -315.1924 & \multicolumn{2}{|c|}{ Hannan-Quinn criter. } & 16.08595 \\
\hline F-statistic & 32.33244 & \multicolumn{2}{|c|}{ Durbin-Watson stat } & 0.461127 \\
\hline $\operatorname{Prob}($ F-statistic) & 0.000000 & & & \\
\hline
\end{tabular}

Sumber: Eviews 7(Data diolah), 2016

Berdasarkan tabel di atas dapat dibuat persamaan regresi linier berganda sebagai berikut :

$$
\mathrm{PDRB}=\boldsymbol{\beta 0}+\beta 1 \mathrm{TNK}+\beta 2 \mathrm{PRSH}+\beta 3 \mathrm{EX}+\beta 4 \mathrm{PSYRH}
$$

Dimana:

$\mathrm{PDRB}=9607.126+0.613 \mathrm{TNK}+69.81 \mathrm{PRSH}+0.0042 \mathrm{EX}+0.242 \mathrm{PSYRH}$ 
Dari fungsi model di atas dapat dipahami bahwa :

1) Nilai konstanta 9607.126 menyatakan jika variabel TNK, PRSH, EX, dan PSYRH adalah tetap, maka nilai PDRB Industri Kreatif adalah Rp. 9607.126 miliar.

2) Nilai koefisien TNK 0.613 menyatakan jika TNK meningkat 1 (orang) maka akan meningkatkan PDRB Industri Kreatif sebesar Rp. 0.613 persen. Sebaliknya, jika TNK berkurang 1 (orang) maka akan menurunkan PDRB Industri Kreatif sebesar Rp. 0.613 persen. Di sini TNK memiliki pengaruh yang signifikan terhadap PDRB Industri Kreatif. Semakin tinggi jumlah TNK menyebabkan naiknya nilai PDRB Industri Kreatif.

3) Nilai koefisien PRSH 69.81 menyatakan jika PRSH meningkat 1 unit maka akan meningkatkan nilai PDRB Industri Kreatif sebesar Rp. 69.81 miliar atau meningkatkan nilai PDRB Industri Kreatif sekitar Rp. 698 juta. Sebaliknya, jika PRSH menurun 1 unit maka akan menurunkan nilai PDRB sebesar Rp 69.81 miliar atau menurunkan nilai PDRB Industri Kreatif sekitar Rp. 698 juta. Di sini PRSH memiliki pengaruh yang signifikan terhadap PDRB Industri Kreatif.

4) Nilai koefisien EX 0.0042 menyatakan jika EX meningkat Rp. 1 miliar, maka akan meningkatkan PDRB Industri Kreatif sebesar Rp. 4,2 miliar. Sebaliknya, jika EX turun Rp. 1 miliar, maka akan menurunkan PDRB Industri Kreatif sebesar Rp. 4,2 miliar. Di sini EX memiliki pengaruh yang signifikan terhadap PDRB Industri Kreatif.

5) Nilai koefisien PSYRH 0.242 menyatakan jika PSYRH meningkat Rp. 1 miliar, maka akan meningkatkan PDRB Industri Kreatif sebesar Rp. 242 Juta Sebaliknya, jika PSYRH turun Rp. 1 miliar, maka akan menurunkan PDRB Industri Kreatif sebesar Rp. 242 Juta. Di sini PSYRH memiliki pengaruh yang signifikan terhadap PDRB Industri Kreatif. Semakin tinggi nilai PSYRH menyebabkan naiknya nilai PDRB Industri Kreatif.

\section{UJI HIPOTESIS}

Uji F-test digunakan untuk menguji pengaruh secara bersama-sama (simultan) pada variabel TNK, PRSH, EX, dan PSRYH mempengaruhi PDRB Industri Kreatif. Dari hasil estimasi pada Eviews 7 diperoleh hasil sebagai berikut.

Tabel 4.11

Hasil Pengujian Uji-F

\begin{tabular}{|c|c|}
\hline F-statistic & 32.33244 \\
\hline Prob(F-statistic) & 0.000000 \\
\hline
\end{tabular}

Sumber : Data diolah, 2016. 
Berdasarkan hasil pengujian di atas dapat dilihat nilai F-hitung adalah 32.33244 dengan nilai probabilitas adalah 0,000000. Nilai F-tabel untuk jumlah observasi sebanyak 40 dengan tingkat signifikansi $5 \%$ dan $\mathrm{k}$ atau jumlah seluruh variabel baik variabel independen dan dependen adalah 5 , maka nilai $\left(\mathrm{N}_{1}=\mathrm{k}-1=5-1=4\right),\left(\mathrm{N}_{2}=\mathrm{n}-\mathrm{k}-1=40-5\right.$ $-1=34$ adalah 2,65). Sehingga diperoleh bahwa F-hitung lebih besar dari F-tabel atau $32.33244>2,65$ dan juga dapat dilihat pada nilai probabilitas lebih kecil dari tingkat signifikansi (a) 5\% atau 0,000000 < 0,05 maka dapat diambil kesimpulan bahwa TNK, PRSH, EX, dan PSRYH secara bersama-sama mempengaruhi PDRB Industri Kreatif kesimpulan $\mathrm{H}_{\mathrm{o}}$ ditolak.

Uji t-test digunakan untuk melihat hubungan atau pengaruh antara variabel TNK, PRSH, EX, dan PSRYH secara individual (parsial) terhadap variabel PDRB Industri Kreatif. Pada uji t dalam penelitian ini, ternyata terlihat bahwa variabel jumlah tenaga kerja, jumlah perusahaan, jumlah ekspor dan jumlah pembiayaan syari'ah secara parsial mempengaruhi PDRB Industri kreatif di Sumatera Utara.

\section{SIMPULAN}

Dari pembahasan penelitian ini, maka hasil yang didapat adalah :

Hasil penelitian secara bersama-sama menunjukkan bahwa sekitar 76,2\% variabel TNK, PRSH, EX, dan PSYRH mempengaruhi PDRB Industri Kreatif di Sumatera Utara periode 2006 - 2015, sedangkan 23,8 \% dijelaskan oleh faktor-faktor lain. Jumlah Tenaga Kerja (TNK) memberikan pengaruh signifikan terhadap PDRB Industri Kreatif di Sumatera Utara artinya semakin meningkat TNK maka semakin meningkat PDRB Industri Kreatif di Sumatera Utara. Jumlah Perusahaan (PRSH) memberi pengaruh signifikan terhadap PDRB Industri Kreatif di Sumatera Utara, hal ini mengindikasikan bahwa semakin banyak jumlah perusahaan, maka semakin meningkat PDRB Industri Kreatif di Sumatera Utara. Jumlah Ekspor (EX) memberi pengaruh signifikan terhadap PDRB Industri Kreatif di Sumatera Utara, Hal ini mengindikasikan bahwa semakin banyak Jumlah ekspor, maka semakin meningkat PDRB Industri Kreatif di Sumatera Utara. Jumlah Pembiayaan Syari'ah (PSYRH) memberi pengaruh signifikan terhadap PDRB Industri Kreatif di Sumatera Utara, hal ini mengindikasikan bahwa semakin meningkat PSYRH maka akan semakin meningkat PDRB Industri Kreatif di Sumatera Utara.

Penelitian ini merekomendasikan perlu adanya perhatian dari pemerintah terutama dalam membantu para pelaku usaha untuk mengembangkan usahanya dengan memberikan fasilitas bantuan modal dari bank-bank syariah karena bank syariah menggunakan prinsip syariat dalam menjalankan fungsinya sebagai penyedia dana dan keuntungan tidak sepihak sehingga tidak merugikan para pengusaha. Maka semakin 
berkembangnya para pengusaha maka semakin meningkat juga pembiayaan syariah dan jumlah perusahaan sehingga hal ini dapat meningkatkan PDRB Industri Kreatif di Sumatera Utara.

\section{PUSTAKA ACUAN}

Adriyanto Irsyad, "Analisis Peran Keterlibatan Kerja Dalam Hubungan Etika Kerja Islam Dan Sikap Terhadap Perubahan,” dalam Iqtishadia, Vol 9 No.1. 2016, h. 6.

Akmal Tarigan, Azhari. Teologi Ekonomi Jakarta: RajaGrafindo, 2014

Badan Pusat Statistik Sumatera Utara. Sumatera Utara Dalam Angka 2016. Katalog BPS No. 1102001.12 (Medan: BPSSUMUT,2016) pdf.

Berita Resmi Statistik Sumatera Utara. Industri Triwulan I Tahun 2015 No.32/05/12/ Thn. XVIII, 4 Mei 2015.

Budi Sasono, Herman. Manajemen Ekspor dan Perdagangan Internasional Yogyakarta: Andi Offset, 2013

Diah Citraresmi Cahyadi, Luh "Analisis Faktor Yang Mempengaruhi Penyerapan Tenaga Kerja Industri Kreatif Di Kota Denpasar" Tesis Pascasarjana Fakultas Ekonomi Udayana Bali, 2013

Fauzia, Ika Yunia dan Abdul Kadir Riyadi. Prinsip Dasar Ekonomi Islam Perspektif Maqashid al-Syariah Jakarta: Kencana, 2014

Gujarati, Damodar Gujarati. Ekonometrika Dasar, terj. Sumarno Zain Jakarta: Erlangga, 1988

Ismail, Perbankan Syariah Jakarta: Kencana, 2011

Jhingan, M.L. Ekonomi Pembagunan dan Perencanaan, terj. D.Guritno Jakarta: RajaGrafindo, 2004

Jogiyanto, Metodologi Penelitian Bisnis:Salah Kaprah dan Pengalaman - Pengalaman Yogyakarta: BPFE, 2007

Mankiw, Gregory. Makroekonomi. Ahli Bahasa: Fitria Liza, S.E dan Imam Nurmawan, S.E Jakarta: Erlangga, 2006

Rakhmawati, Istina. "Dampak Produktivitas Kerja Islami Bagi Kinerja Karyawan”, dalam Iqtishadia, Vol 9. No.1. 2016

Rosadi,Dedi. Ekonometrika \& Analisis Runtun Waktu Terapan dengan Eviews Yogyakarta: Andi Offset, 2012

Saefuddin, AM. Membumikan Ekonomi Islam Jakarta: PT PPA Consultants, 2011

Setiawan dan Endah Kusrini, Ekonometrika Yogyakarta:Andi Offset, 2010

Solachuddin Zulfa, Moh. "Analisis Tentang Manajemen Resiko Dalam Operasional Pembiayaan Murabahah di BMT Amanah," dalam Iqtishadia, Vol7.No.1, 2014 
Erni Yusnita Siregar, Saparuddin Siregar, Andri Soemitra: Industri Kreatif

Sukirno, Sadono. Teori Pengantar Makroekonomi Jakarta: RajaGrafindo ,2015

Suryana, Ekonomi Kreatif Ekonomi Baru: Mengubah Ide dan Menciptakan Peluang Jakarta: Salemba Empat, 2012

Syofian Siregar, Statistik Parametrik untuk Penelitian Kuantitatif Jakarta: BumiAksara, 2014

Sutedi, Andrian. Hukum Eskpor Impor Jakarta: Penebar Swadaya Group, 2014 